DOI: 10.17805/ggz.2019.1.2

\title{
Русофобия Запада, построенная на современных событиях: когда идеологемы противостоят реальности
}

\author{
А. Н. Ильин \\ Омский государственный педагогический университет
}

В статье анализируются современные обвинения западных стран в отнотении России. Среди них убеждение во влиянии российских спецслужб на выборы в США, вина России за отравление Скрипалей и т. д. Автор скрупулезно рассматривает внутреннее содержание этих обвинений, их логику и фактологическую основу и доказывает абсурдность и необоснованность русофобии. Продемонстрировано, как на основе одних недоказанных обвинений строится целая цепочка других необоснованных обвинительных актов. Также раскрываются основные причины возобновившейся информационной атаки в отношении России со стороны Запада.

Ключевые слова: русофобия; Россия; США; Запад; С. В. Скрипаль; информационное общество

\section{Russophobia of the West Based on Contemporary Events: When Ideologemes Are Confronted with Reality}

\author{
A. N. Ilyin \\ Omsk State Pedagogical University
}

The article analyzes the modern accusations of Western countries against Russia. Among them there are: the conviction that Russian intelligence services have had an influence on the elections in the United States, Russia's blame for poisoning Skripals, etc. The author meticulously examines the internal scope of these charges, their logic and factual basis, and proves the absurdity and groundlessness of Russophobia. It is demonstrated how the whole chain of other unsubstantiated indictments is built on the basis of some unproven accusations. It also reveals the main reasons for the resumed information attack against Russia launched from the West. ciety

Keywords: Russophobia; Russia; USA, West; S. V. Skripal; information so-

\section{ВВЕДЕНИЕ}

Русофобия - явление далеко не новое. Оно имело место и в прошлые эпохи. И практически всегда оно основывалось на ложных доводах, необоснованно демонизирующих нашу страну. Конечно, всегда высказывались оправдания, апеллирующие к тому, что в России недостаток демократии, 
коррупция, притеснения каких-либо социальных меньшинств, у Кремля амбициозные цели влияния на другие страны и т. д. Но, во-первых, ряд подобных проблем свойственны нашим геополитическим противникам - западным странам. Поэтому актуальна ответная фраза: “Look at yourself”. Boвторых, многие приписываемые России проблемы и амбиции на самом деле ей не свойственны и являются псевдоинформационными феноменами.

Независимо от политической системы, выстроенной в России, мы будем ощущать на себе нападки атлантизма. И сколько бы ни говорили о недостатке демократии в РФ, дело вовсе не в ней. Просто нужны различные поводы на все случаи жизни, чтобы обосновать претензии «цивилизованного» мира к их непокорному северному коллеге. Дело здесь исключительно в геополитике, а именно в стремлении сильных мира сего покорить относительно непокорную страну. Анализ причин и внутренних особенностей русофобии мы начали в предыдущих работах (Ильин, 2017b, 2018bc). В настоящей статье мы продолжим рассмотрение этого феномена на примере современных антироссийских выпадов.

Сконструированные нашими геополитическими и геоэкономическими противниками мифы хорошо коррелируют с давно сформировавшейся на Западе нарциссичной системой убеждений, которую мы называем культурным западоцентризмом. Как пишет А. Г. Дугин, «западное общество исторически складывалось как общество, считавшее свои ценности, идеалы, нормативы и принципы универсальными. Начиная с IX в. Западная Европа постепенно размежевывалась со своими греческими корнями, создавая особую романогерманскую социокультурную систему, которая претендовала на универсализм и монополию на истину. Через средневековую схоластику, продолжившую эту линию, Западная Европа постепенно реализовывала тот же самый подход и в философии Нового времени, заменив универсальность католической церкви на универсальность демократии, свободы, либерализма, а после И. Канта - “гражданского общества”. Сами ценности, социальные и политические формы их реализации менялись, но убежденность Запада в том, что именно европейское общество обладает монополией на истину, сохранялась и сохраняется по сей день. В этом проявляется культурный империализм Запада, убежденного в том, что только западное общество является венцом цивилизации, а все остальные типы культур призваны ему подражать и следовать ему под страхом остаться вне “цивилизованного мира"» (Дугин, 2011: 89).

Для российского общества и его культуры возрастают серьезные трудности, когда мы в явной или неявной форме соглашаемся с западной монополией на истину. Поэтому для самосохранения, для упрочения национальной безопасности необходим решительный отход от принятия культурного империализма, называемого глобализацией, от пиетета перед западной культурой. Безоценочно принимая ее, мы рискуем двинуться к соглашательской позиции в экономике, геополитике, духовном облике, что повлечет экономическое, геополитическое, культурное ослабление России. 
Бытовые формы русофобии известны издавна. Они вроде бы отдаленно относятся к политической сфере по своему содержанию, но в целом любые проявления русофобии поддаются политизации. Когда в бытовом, повседневном (или просто неполитическом) смысле очерняют Россию, это дает еще один аргумент политикам, своим долгом считающим втоптать Россию в грязь. Поэтому, когда речь идет даже о мелких формах непотребного (бескультурного) поведения русских в быту, их алкоголизме и т. д., повседневность легко конвертируется в политику.

Так, американские и европейские пропагандисты выдают за факт, что русская национальная идея - водка, а проявление русской ментальности безудержное ее распитие. Да, проблема алкоголизации проявляет себя довольно остро, но это не значит, что она всегда стояла на первом месте, равно как из этого нельзя сделать вывод о том, что иностранцы меньше пьют. Для некоторых стран эта проблема, пожалуй, кажет себя в еще более остром ракурсе. В тех же Ирландии и Германии местное народонаселение выпивает столько спиртного, что нашим богатырям даже и не снилось. Этот миф о русской ментальности, как и другие, был сознательно конституирован и внедрен в общественное сознание для дискредитации России как геополитического конкурента и ее основного этноса.

В некоторых случаях можно наблюдать следующую цепочку событий: заинтересованные в росте антирусских настроений западные политики формируют определенный воспитательный тренд через СМИ, последние пропагандируют русофобские идеи, многочисленные реципиенты ими наполняются, после чего власти переходят к решительно антирусской внешней политике, прикрываясь господствующими настроениями в их обществе. Получается так: сами создали общественное мнение, а потом им оправдали свои действия. Вроде бы демократично. Почти как в коммерческом маркетинге, который предлагает вместо производства товаров под уже существующие потребности формировать потребности под выпускаемую продукцию.

В. Морозов пишет относительно демонизации России в США и Западной Европе: «Важными факторами здесь являются поиск сенсаций средствами массовой информации, стремление левых интеллектуалов на российском примере подчеркнуть гибельность неолиберальной глобализации, а также внутриполитическая конкуренция между демократами и республиканцами в Соединенных Штатах» (Обзор ... , 2004: Электронный ресурс). На наш взгляд, эти причины - всего лишь поверхность. Главная причина очернения России - банальные интересы. Здесь и заключается «банальность зла». Речь идет не о желании каких-то отдельных групп (журналисты, коммунисты и т. д.) достичь неких групповых целей. Смотреть нужно не на отдельные групповые интересы, а на консолидированный интерес западных элит настроить мировую общественность против геополитического соперника, а также повернуть российское общество против своей страны и ее истории. Конечно, когда мы говорим о Западе, то имеем в виду не всех без исключения политиков и корпоратократов, а именно тех, кто обладает наибольшей 
силой и влиянием, от кого зависит повестка дня.

Даже экологическая проблематика дает много возможностей для русофобской истерии. Давно известно, что большинство так называемых экоактивистов шельмуют Россию за выбросы вредных веществ в атмосферу и мировой океан, но про западные страны умалчивают, как будто они представляют собой «экологических святых». Однако Запад совершает колоссальное количество выбросов вредных отходов (см.: Грешневиков, 2003). Но им можно, а нам - нет. Таким образом, двойные стандарты как главное идеологическое оружие Запада интегрировались в том числе и в экопроблематику (о двойных стандартах см.: Ильин, 2017а, 2018а).

\section{НЕСКОЛЬКО СЛОВ О ДЕМОКРАТИИ}

На Западе утвердилось мнение, что законы в России дисфункциональны, Конституция «плачет в углу», а демократия существует только в демагогических высказываниях. Конечно, проблем, связанных с законностью и народовластием, довольно много. Но когда Штатами управляют политики, сращенные с крупнейшим бизнесом (и бизнесмены занимают высокие государственные посты), стоит вести речь одновременно о коррупции и недостатке демократии. Банально говорить о противоположности интересов народа и бизнеса.

Примерно похожие процессы происходят в Европе, где те же транснациональные корпорации и работающие в их интересах вашингтонские политики наращивают свое влияние, не особо оглядываясь на интересы народного большинства. Приведем взятый из статьи А. И. Фурсова факт. Вышедший в отставку генерал немецкой разведки Герд-Хельмут Комосса рассказал о существовании документа под названием «канцлер-акт». В мае 1949 г. власти оккупированной Германии были вынуждены подписать со Штатами документ (срок действия - 150 лет), согласно которому кандидатура канцлера ФРГ утверждается в Вашингтоне, внутренняя и внешняя политика, а также политика в области образования и СМИ в значительной степени тоже определяются американским «обкомом». По утверждениям Камоссы, «канцлеракт» действует и поныне. При учете наличия американских баз в ФРГ и контроля над общественным мнением, нынешнюю Германию можно назвать протекторатом США даже при всех ее экономических успехах (Фурсов, 2013).

К тому же европейский быт намного более регламентирован и бюрократизирован, чем в России. Просто регламентация обыденной жизни едва ли представляется европейцам антидемократичной, поскольку она давно стала плотью и кровью бытия, формой культуры и совокупностью социальных норм.

Вопрос о «независимости» западных СМИ - отдельная тема. Вспомним весьма содержательные и до сих пор не опровергнутые книги о функционировании американских медиа; например, знаменитую работу Г. Шиллера «Манипуляторы сознанием» (Шиллер, 1980). Вспомним, как специально 
скрывались улики после 11 сентября 2001 г., на место происшествия не допускались журналисты, а сторонники альтернативных версий сталкивались с ситуацией отсутствия возможности высказаться в прессе. Вспомним, как «цивилизованные» медиа демонизировали С. Милошевича за то, что он не хотел проводить приватизацию и давать возможность транснациональному бизнесу скупить югославские активы. А. Тарасов отмечает, как знакомые ему «американские профессора дружно жаловались, что ни одно издание не хочет печатать их статьи с критикой НАТО, а TV отказывается от интервью сразу, как только выясняет, что они - противники войны в Югославии» (Тарасов, 2011: Электронный ресурс; курсив источника. - A. И.). Также А. Тарасов приводит пример, как теоретик итальяно-люксембургианской организации “Socialismo rivoluzionario” был потрясен, узнав о существовании в XX веке немалого числа итальянских же философов-марксистов, - ему известен был исключительно Антонио Грамши. Наверное - особое проявление независимости западных СМИ связано с тем, что они не видят в нацистском перевороте на Украине «ничего такого» и замалчивают о происходящем нацистском бесчинстве с убийствами и сожжениями людей. И разве сейчас не выкрикивают западные СМИ практически в унисон массу бездоказательных обвинений против России?

В США нет принципиальной разницы между так называемыми демократической и республиканской партиями, альтернативность между ними предполагает выбор без выбора. Каждый новый президент независимо от его партийной принадлежности продолжает дела своего предшественника обязательно кого-то бомбит, где-то устраивает «цветные революции», и сращенная с американским истеблишментом «несвятая троица» - МВФ, ВТО и Всемирный банк - продолжает ловить различные государства в экономические ловушки. Коммунистические партии не представлены ни в политическом, ни в медийном поле. Поэтому выбирать приходится между капитализмом и капитализмом. Происходящее напоминает описанный Ги Дебором спектакль, при котором публике демонстрируется мнимая принципиальность конфликтов между двумя сторонами.

Крупнейшие американские политики занимают высокие должности в корпоративном секторе, что является узаконенной коррупцией (на политкорректном языке это называется лоббированием). Занять ключевые политические посты невозможно без экономической поддержки крупнейших бизнесакторов. Попасть в список кандидатов на высокий пост можно при наличии серьезных финансовых, медийных и иных ресурсов. Недостаточно обеспеченным представителям народа в серьезную политику дорога закрыта. Стоит говорить о закупоривании возможностей инкорпорирования во власть «снизу». Но классовый подход никто не отменял, и очевидно, что интересы корпоратократии противоречат интересам народа. К тому же если экономическая власть принадлежит частным заправилам Федеральной резервной системы, то в их руках концентрируются и рычаги влияния на политическую власть. Следовательно, правительство вынуждено принимать многочислен- 
ные политические решения в интересах крупнейшего бизнеса - в ущерб интересам американского народа. Богатство влияет на политику крайне сильно: «Когда говорят деньги, - все остальные обречены слушать. По этой причине демократическое общество не может допустить неограниченного накопления. Социальное и гражданское равенство предполагает по крайней мере грубо-приблизительное экономическое равенство» (Лэш, 2002: 21).

Стоит обратить внимание на множество фактов, как Дж. Буш младший (а затем Б. Обама), ссылаясь на мифическую войну с терроризмом и прикрываясь трагедией 11 сентября, принялись наступать на гражданские права и свободы, ограничивать свободу слова, прикрывать незаконные аресты. Стало нормой похищать и бросать на длительный срок в тюрьмы без суда и следствия людей под надуманным предлогом об их предполагаемой связи с АльКаидой. Те, кто осуждал КНР и другие страны за ограничение доступа к Интернету и неприятие свободы печати, вооружившись обвинениями в шпионаже, принялись охотиться на Дж. Ассанжа и других людей, связанных с Wikileaks ${ }^{1}$.

Можно многое написать об антидемократических аспектах западной политики и жизни. Можно вспомнить, что в США вместо народа голосуют выборщики, а в Германии люди на выборах ставят галочки за кандидатов карандашом. Но у нас нет цели представить вниманию читателя многообразие антидемократических тенденций «той стороны».

Конечно, некоторые похожие проблемы характерны и для России. Но дело не в сравнении между странами, а в постулировании простого тезиса: весьма лицемерно выглядят слова о том, что США — форпост демократии, а РФ - территория авторитарного самодержавия.

Тенденция лицемерной критики политических противников не нова; она проявлялась и в годы холодной войны. Так, в 1978 г. президент США Дж. Картер предал осуждению приговор советскому диссиденту Анатолию Щаранскому, который получил 13 лет по обвинению в шпионаже в пользу ЦРУ. Вместе с тем Дж. Картер и 3. Бжезинский заигрывали с Китаем, в котором ситуация с правами человека была значительно хуже. Бжезинский признавал в разговорах с Картером, что в Китае ежегодно казнят не менее 20 тысяч заключенных. Американский представитель в ООН Эндрю Янг сказал французскому журналисту, что в тюрьмах США «содержатся сотни, возможно, даже тысячи человек, которых можно назвать политзаключенными» (Drumbell, 1995: 102; цит. по: Стоун, Кузник, 2014: 551). Добавим, что до приговора Щаранскому американцы активно поддерживали катастрофически антидемократические режимы иранского шаха Мохаммеда Реза Пехлеви, заирского Мобуту, чилийского Пиночета, никарагуанского Сомосу и многих других кровавых диктаторов. Когда нарушения прав человека происходят в стане оппонента, их нужно критиковать - критиковать за то, что делают са-

\footnotetext{
${ }^{1}$ О многих беспрецедентных фактах наступления на демократию и права человека со стороны американцев см.: Стоун, Кузник, 2014.
} 
ми американцы и позволяют делать своим союзникам, причем делать со значительно большим рвением, усердием и градусом кровавости, чем их соперники.

В 2015 г. акционеры ЮКОСа отсудили у России в Гааге \$50 млрд по надуманному предлогу, что якобы банкротство компании - дело политическое. Европейский суд, естественно, не заинтересовался тем, что ЮКОС, как и многие другие предприятия, был незаконно приватизирован, т. е. данный сегмент отрасли просто отобран у народа. Гаагский суд не заинтересовался виновностью ЮКОСа в неуплате налогов, а еще и в нескольких заказных убийствах. На том же Западе уклонение от налогов строго карается. Но если уклонитель родом из России, то его, как и многих крайне одиозных российских олигархов, можно принять в Европе с распростертыми объятиями и еще назвать жертвой путинизма. Ведь вредили они не Европе... И при этом представители «цивилизованного» мира обвиняют Россию в высоком уровне коррупции. Были бы грудью против коррупции - с удовольствием отдавали бы нам сбежавших в их лоно воров и не приводили бы к власти коррупционных политиков вроде тех, что сейчас хозяйничают на Украине.

Однако беззаконие и авторитаризм, с точки зрения западных пропагандистов, царят именно в России. Один миф становится идеологическим плацдармом для выстраивания другого мифа. Так, убежденность в извечном российском авторитаризме выступает доказательством не менее извечного российского экспансионизма. Хотя очевидно, что авторитарная власть вовсе не всегда в качестве своего неотъемлемого свойства имеет стремление к имперскости и захвату чужих земель.

\section{СПОРТ ВНУТРИ ГЕОПОЛИТИКИ}

Вроде бы лишенные связи с политикой события подвергаются политизации. Например, во время проходившего во Франции чемпионата мира по футболу 2016 г. именно Россия подверглась необоснованному остракизму. Причиной послужила драка между английскими и российскими фанатами. Несмотря на то, что инициаторы драки не были выявлены, а болельщики из Великобритании вели себя в Марселе откровенно нагло и открыто провоцировали российских болельщиков оскорблениями, полнота обвинительной речи обрушилась на русских. В городе собралась многотысячная толпа вольготно ведущих себя британских фанатов, а российских фанатов было значительно меньше; но и этот — количественный - фактор не остановил антироссийскую идеологизацию. Многочисленные британские фанаты устроили дикий вандализм, учинили в Марселе погром еще до появления там русских ультрас. Потом они принялись топтать флаги России и выкрикивать оскорбления в адрес русских. А виноватыми остались немногочисленные российские поклонники футбола. Провокационные действия болельщиков из других стран просто игнорировались, а многие стычки стали подаваться как инициированные русскими - даже те, в которых наши сограждане не принимали участие. За беспорядки условно дисквалифицировали именно сборную Рос- 
сии, но Великобританию чаша сия миновала. Ведь представители «цивилизованного» мира априори лучше русских, независимо от того, что эти «цивилизованные» творят.

СМИ запестрили сообщениями о нападении крушащих все подряд русских бандитов на английских болельщиков. Российских болельщиков ждали аресты и депортация. Французские власти вместо поиска зачинщиков и участников беспорядков задерживали именно российских болельщиков. Дошло до запрета в городе Лилль нашим болельщикам использовать национальную атрибутику. Участились призывы лишить Россию статуса хозяина чемпионата мира 2018 г., что равнозначно снижению международной репутации России. Создавалось общественное мнение о том, что «русские дикари приехали на чемпионат Европы избивать мирных английских болельщиков» (Сикорский, 2016: Электронный ресурс).

В скандале с российскими болельщиками отличился и главный редактор радиостанции «Эхо Москвы» А. А. Венедиктов. Он опубликовал фотографию, сделанную в 2013 г. в Полтаве и изображающую болельщиков из Харькова, под видом фотографии агрессивных русских с матча в Марселе в 2016 г. На фото были запечатлены одетые в пуховики люди, что для марсельских жарких событий не характерно (Голованов, 2016: Электронный ресурс). После массовой критики Венедиктов признал ошибку, но ошибка ли это? Собственно, ряд либеральных журналистов не впервые расписываются во лжи, фальсификациях и инсинуациях в интересах русофобских сил. На основе множества таких «сообщений» следует поставить вопрос о профессиональной компетентности их как журналистов. Ведь они всегда возмущены агрессивным поведением русских - даже тогда, когда это агрессивное поведение никем не доказано, но постулируется западными СМИ, столь уважаемыми нашими либералами. Последние заражены идеей априорной виновности русских, и их профессионализм, видимо, не предполагает проверки фактов, когда дело касается очередного гряземетания в сторону России. Этим они очень похожи на безответственные западные СМИ, которые в последние годы бьют все рекорды по тиражированию огромного количества лишенных основы обвинений в адрес России. Но такие безответственные либералы должны радоваться - ведь они достигли уровня тех, перед кем склоняют головы и на которых издавна стараются равняться.

Многие украинские СМИ принялись заявлять о том, что на Евро-2016 приехали переодетые в украинцев курсанты из России с целью избиения мирных болельщиков. Украинский «аналитик» Олег Пономарь назвал массовую драку между российскими и британскими фанатами в Марселе грамотно спланированной акцией российских спецслужб, заинтересованных в том, чтобы Великобритания вышла из Евросоюза и тем самым заложила основу для дальнейшего развала ЕС. Мол, если бы королевский подданный погиб, это вызвало бы реакцию у британского общества с призывами отделиться от происходящего (Коломиец, 2016: Электронный ресурс). Может быть, России и выгоден клин между странами ЕС. Однако королевский подданный остался 
жив, и даже если бы кто-то из британских болельщиков полег близ футбольного поля в Марселе, нет оснований говорить, что общественность Туманного Альбиона на этой почве потребовала бы выхода из Евросоюза. Даже если бы правительство Великобритании столкнулось с такой позицией общества, это вовсе необязательно привело бы к лояльности властей общественному мнению. Только свидомые и подобные им российские либералы считают Европу в целом и Великобританию в частности предельно демократическими странами, где воля народа - закон.

Наконец, можно ценить богатое воображение и полет фантазии украинских «аналитиков», но в тезисе Пономаря и ему подобных не хватает самой малости - доказательств причастности российских спецслужб к событиям в Марселе и оснований для «факта» прибытия переодетых российских курсантов ради избиения кого бы то ни было. На вопрос «Кому выгодно?» он, возможно, и ответил, но этого мало для серьезного утверждения. Хотя в последнее время украинские «аналитики» очень активно высасывают «факты» из пальца, смакуя любые новости, в которых участвует Россия и интерпретацию которых можно развернуть в русофобской манере. Эта манера заменяет им доказательную базу. Когда в словах есть антироссийская составляющая, обоснования не нужны. Перефразируя известную фразу, можно сказать: русофобия есть - доказательств не надо.

История про мельдоний — отдельная иллюстрация западного лицемерия. Санкции в отношении российских спортсменов поддержали те же страны, что и устроили экономическую санкционную истерию против России. Спорт - один из аспектов политики. Политизируются как спорт, так ситуация с сексуальными меньшинствами, присуждением премий (в том числе Нобелевской), проведением конкурсов (например, «Евровидение») и т. д.

Нашим спортсменам отказали в праве выступать под российским флагом - конечно же, под очередным надуманным предлогом. Доказательная база «спортивных» гряземетателей, настроенных против России, основывается на свидетельствах Г. М. Родченкова - руководителя московской антидопинговой лаборатории, который убежал из страны и принялся бросаться голословными обвинениями в адрес спортсменов РФ. Его слова остаются словами, но если они направлены против России, то воспринимаются как априори верные. На некоторых пробирках с допинг-пробами российских спортсменов были обнаружены царапины, которые указывают на взлом. Но это для «беспристрастных» западных аналитиков не аргумент. Может быть, подобные царапины присутствуют и на пробирках допинг-проб спортсменов из иных стран. Это просто никому неинтересно. Также как неинтересны для Международного олимпийского комитета признания американского поставщика допинга (Вассерман, 2017: Электронный ресурс).

После того как Международный олимпийский комитет отстранил пожизненно 43 российских спортсмена от Олимпийских игр, решил отказать в допуске российских спортсменов на Олимпиаду и даже запретить одежду с российской символикой, ряд наших олимпийцев были оправданы в высшем 
Спортивном арбитражном суде (Court of Arbitration for Sport, CAS). Но это решение МОК в качестве авторитетного не воспринял. Глава МОК выразил мнение о необходимости реформы CAS. Ну конечно, когда орган придерживается иной точки зрения, его нужно реформировать. А как же иначе? Иными словами, все, что противоречит определенной воле, следует подвергать репрессиям. МОКу не нужны никакие доказательства виновности / невиновности наших спортсменов; ведь когда дело касается русских, факты и улики ни к чему. Здесь включается по-настоящему мистическая вера в презумпцию виновности русских, и если эта вера опровергается фактами, тем хуже для фактов. Вся недавняя история олимпийского мракобесия показывает, что российские спортсмены становятся персонами нон-грата просто так, без внятных обвинений. На самом деле причина маргинализации российских спортсменов проста - международные спортивные чиновники приняли на свою грудь политизацию и активно прислуживают тем, кто себя провозгласил хозяевами этого мира.

Наши геополитические противники руками международных спортивных организаций пытаются выбить из России признание в существовании системы государственной поддержки допинга. Проблема в том, что обосновать наличие сего не получается; у обвинителей отсутствуют четкие, конкретные и достаточные доказательства. Но этот факт не умеряет их пыл оказывать давление на Россию.

\section{КАК ТРАМП В БОЛЬНОМ ВООБРАЖЕНИИ СТАЛ АГЕНТОМ КРЕМЛЯ}

Особым событием стало обвинение Кремля во вмешательстве в американские президентские выборы. Директор ЦРУ М. Помпео даже заявил, что Россия десятилетиями вмешивается в выборы в США (Глава ЦРУ ... , 2018: Электронный ресурс). Это необоснованное заявление вызывает обоснованные вопросы. Если так, то почему именно сейчас сказаны слова о таком длительном вмешательстве, почему об этом умалчивалось на протяжении этих десятилетий? Как так получается, что Россия вмешивается в выборы США, а Штаты продолжают реализовывать антирусскую политику? Неужели вмешательство Москвы настолько слабое, что не может противодействовать нападкам на Москву со стороны Вашингтона? Почему-то Россия не смогла повлиять на американскую политику так, чтобы элиты США отказались выделить деньги и другие ресурсы на украинский госпереворот, крайне нежелательный для РФ. Или, может быть, вмешательство Москвы настолько слабое, что позволительно говорить о его отсутствии? Господин Помпео совершил артикуляционные движения, несущие определенное содержание, но доказать какими-либо фактами последнее не потрудился. Ведь не было предъявлено обоснований вмешательства России в выборы США, да еще и многодесятилетнего.

Х. Клинтон однажды разразилась следующей тирадой: «Только вчера наиболее известный лидер правых в Британии, человек по имени Найжел 
Фараж, подогревавший антииммигрантские настроения... агитировал за Д. Трампа в Миссисипи. Фараж требовал запрета для детей мигрантов посещать школы и пользоваться медицинскими услугами. Он сказал, цитата: “женщины стоят меньше, чем мужчины”, и он поддерживает инициативу отменить законы, не позволяющие расовую дискриминацию на работе. Вот вместе с кем Д. Трамп обращается к американским избирателям, и крестным отцом этого глобального крайнего национализма является российский президент В. Путин. В самом деле, Фараж регулярно появляется на российских пропагандистских каналах, а сейчас он поддерживает номинанта Республиканской партии» (цит. по: Алексеев, 2018: 16). Как видно, американский политик смешала здесь все, что только гипотетически можно смешать, хотя элементарный здравый смысл сопротивляется такому микшированию. Мы видим и негативное отношение к политическому конкуренту Трампу, и спекуляции на национализме, и наклеивание ярлыка на Путина. При этом она не конкретизировала, как именно российский президент стал крестным отцом национализма (да еще и крайнего, глобального), пропагандируемого какимто британским Фаражем. Когда же Путин позволял себе высказываться в националистическом ключе? Где мы видим в России притеснения эмигрантов, национальную или расовую дискриминацию? Если Фараж регулярно появляется на российских пропагандистских каналах, странно, почему в РФ он не имеет статуса известной персоны. Это тот человек, которого знает крайне малый процент населения, а в центральных медиа он вообще не представлен. Получается, Клинтон в своих словах использует обыкновенный обман.

Зараженная милитаризмом X. Клинтон известна также недоказанной позицией, согласно которой WikiLeaks связана с Кремлем. Люди, создавшие этот ресурс, были объявлены вне закона, на их головы американская пропаганда вылила массу обвинений, они подверглись реальным преследованиям только за то, что решили рассказать миру правду о деятельности американских элит. «...государство пытается преследовать в судебном порядке людей, которые разоблачают его преступления» (цит. по: Фуко, 2002: 129), - слова Н. Хомского, которые можно возвести в ранг великого высказывания. Применительно к WikiLeaks и Дж. Ассанжу эта фраза звучала бы так: государство пытается преследовать в несудебном и потому абсолютно нелегитимном порядке людей, которые разоблачают его преступления. Демократия в действии...

В сентябре 2018 г. постпред США при ООН Н. Хейли заявила, что российские спецслужбы причастны к убийству брата Ким Чен Ына. И снова ни единого доказательства не было предъявлено. С таким же успехом можно обвинять русских в убийстве кого бы то ни было где бы то ни было.

Р. Барт использовал термин «нулевая степень письма». Применительно к многочисленным обвинениям России следует говорить о нулевой степени риторики. Под нулевой степенью в данном случае мы понимаем содержательную пустоту, ничтожность и фактологическую ущербность.

На основе смехотворных обвинений реализуется совсем не смехотвор- 
ная политика. В США периодически арестовывают российских граждан, хотя юридические претензии к ним выглядят ничтожными. Вспомним дело В. А. Бута. Недавно арестованную М. В. Бутину обвиняют непонятно в чем. Складывается впечатление, что ей инкриминируют просто общение с гражданином США. Видимо, с недавних пор коммуникация между гражданами разных стран стала преступлением. Однако почему-то американцы не торопятся арестовывать по аналогичным основаниям российских защитников либерализма, которые посещают американское посольство, активно общаются с представителями государства-гегемона и ездят в США.

\section{СКАНДАЛ ВОКРУГ ОБВИНЕНИЯ С. В. СКРИПАЛЯ}

Наших геополитических «партнеров» не смущает отсутствие доказательств причастности российских спецслужб к смерти российского силовика А. В. Литвиненко, журналистки А. С. Политковской и к отравлению в Великобритании бывшего сотрудника ГРУ С. В. Скрипаля. Скрипаль ранее был арестован сотрудниками ФСБ и обвинен в сотрудничестве с британской разведкой; вину он признал. Позже он был помилован, и его обменяли вместе с другими разведчиками на арестованных в Великобритании за шпионаж россиян. В Туманном Альбионе Скрипаль в MI-6 читал лекции о российской военной разведке, о ее методах работы, а также давал консультации об эффективном противодействии российским спецслужбам (Фахрутдинов, 2018: Электронный ресурс). Но все эти факты вовсе не могут выступать достаточным доказательством обвинения в сторону России. Напротив, Скрипаль, учитывая его биографию, является удобной жертвой для наших противников. Ведь можно разработать прекрасную схему — отравить российского предателя в Великобритании, потом заявить о причастности спецслужб РФ и выложить на стол идею (только лишь идею), будто российские силовики отомстили ему за предательство.

Незадолго до этого события по телевидению Великобритании показывали сериал «Ответный удар» (“Strike Back”), который был снят при поддержке британских военных. В сюжете одного из сезонов имел место нервнопаралитический отравляющий газ «Новичок», изобретателем которого является русский ученый (Красько, Ивкина, 2018). Многие телеистории, не запомнившись, остаются в подсознании, и реципиенты не помнят источник информации, но доверяют уже заложенным сведениям. Похоже, в подсознании британцев закладывалось основание для веры, что Россия виновна в отравлении.

Оказывая давление на Москву, Лондон отказывается делиться результатами расследования. Это уже совсем инфантильное, не достойное государственных мужей поведение: «Я просто знаю, что ты виноват». К тому же вместе со Скрипалем была отравлена его дочь, которая является гражданкой РФ, и потому власти Соединенного Королевства обязаны предоставить информацию о расследовании и допустить российских специалистов к Юлии Скрипаль. Но отсутствует как информация, так и допуск. Видимо, никаких 
результатов нет, и делиться нечем. Если бы они имелись, наши геополитические противники не упустили бы возможность дать миру доказательства об очередном преступлении русских. Вместо этого они распространяют голословные обвинения.

«На совещании в Совете национальной безопасности мы договорились предпринять меры по подрыву шпионской сети России в Великобритании и по противодействию враждебной активности. Это самая большая высылка дипломатов за последние 30 лет» (цит. по: Заквасин и др., 2018: Электронный ресурс), - заявила Т. Мэй, которая заодно прямым текстом (и абсолютно голословно) обвинила Россию в отравлении Скрипаля. Откуда данные про какую-то шпионскую сеть? На основе недоказанного «факта» причастности России к покушению на Скрипаля создали и растиражировали другой недоказанный «факт» о шпионской сети русских в Великобритании. Это один из методов манипуляции сознанием: крайне гипотетический (нередко фантастический) тезис преподносится как истинный, и на его основе выводится цепочка других не менее гипотетических тезисов, которые подаются как факты.

Одно из «доказательств» выглядит так: именно в РФ (СССР) разрабатывалось нервно-паралитическое вещество «Новичок», которым предположительно были отравлены Скрипали. Во-первых, ключевое слово - «предположительно». Какое вещество использовалось, неизвестно. Неужели британские эксперты настолько неквалифицированные, что ранее допустили чехарду в определении вещества, которым был отравлен А. В. Литвиненко, долго не проявляли способности установить причину смерти Б. А. Березовского, а теперь не могут определить вещество, подсунутое Скрипалю? Просто нужно «подогнать» вещество под Россию. Во-вторых, из России вывозили в «лихие» 90-е и в начале нулевых все, что только можно и чего нельзя, и, даже если действительно в этом деле использовался «Новичок», он мог быть вывезен кем угодно и куда угодно. В-третьих, не стоит сбрасывать со счетов предположение, что в других странах умеют создавать аналогичные или даже идентичные отравляющие вещества. На основе этого «предположительно» последовало обвинение России в нарушении Конвенции о запрещении химического оружия. Ну разве не лихо? Только предположили - и сразу обвинили. Не выяснены личности исполнителей, не представлено никакой конкретики в расследовании, а виновные уже назначены. Зато крики о злой России побивают все рекорды. Аргументационный дефицит компенсируется эмоциональным профицитом.

Англичане отказались предоставить российским экспертам доступ к веществу, которым были отравлены Скрипаль и его дочь, хотя Конвенция оставляет за подозреваемым право ознакомиться с материалами следствия. Вот такое нынче джентльменство. Получается, именно Лондон нарушает Конвенцию о запрете химоружия, пока не предоставляет доступ. И это нарушение является косвенным доказательством вины британской стороны в отравлении Скрипаля и его дочери. К тому же Соединенное Королевство заблокировало в ООН предложение России к проведению расследования (В СБ 
ООН ... , 2018: Электронный ресурс). Этим британцы показывают нежелание по-настоящему расследовать дело.

Люди, осматривающие место преступление, облачены в защитные костюмы. Рядом с ними стоит человек, лишенный такого одеяния. Его не жаль? Ему костюма не нашлось? Или просто возгласы про отравляющее вещество — фикция?

Позже британцы принялись уничтожать вещественные улики по делу об отравлении Скрипалей. Была вывезена уличная скамейка, на которой нашли пострадавших, убиты домашний кот и морские свинки. Объявлено решение снести дом Скрипаля и ресторан, в котором пострадавшие находились перед отравлением. А почему бы заодно не снести весь Солсбери? Юлию Скрипаль британцы отказались легализовать. Никаких прессконференций, никакого выхода в свет, никаких фотографий, никаких встреч даже с родственниками. Ее сестре было отказано в визе. На суд общественности представлено письмо Юлии, где она выражает нежелание кого-то видеть; только нет уверенности, что письмо действительно написано ею. Ситуация странная до самого сильного изумления. Если Юлия пошла на поправку (как сообщает британская пресса), вполне нормальным стремлением было бы увидеться с близкими. Скорее всего не она испытывает такое коммуникативное нежелание, а спецслужбы Альбиона диктуют правила игры. Если все перечисленное - не заметание следов, то что? Пострадавшим Британия не стремится дать возможность свободно выступать. Мы вообще про них ничего не знаем. Неудивительно, что некоторые люди вообще сомневаются в том, было ли вообще отравление.

Как отметил А. А. Вассерман, «лаборатория в швейцарском городе Шпиц обнаружила в пробах из английского города Солсбери следы вещества BZ. Снадобье, оглушающее на несколько суток, разработано в Великобритании, состояло на вооружении у нее и СГА. В отчете ОЗХО по делу Скрипалей сведения, полученные из Швейцарии, не упомянуты» (Вассерман, 2018с: Электронный ресурс). Это неудивительно, если британцев интересует вовсе не истина.

Требование Британии к российским властям за 24 часа предоставить информацию об отравлении Скрипаля побивает все рекорды нелегитимности. Как невиновный может дать информацию о преступлении? Тут же предполагается априорная виновность, основанная на мнениях и больше ни на чем. Не обвиняемый должен доказывать свою невиновность, а обвинитель его вину. Но, когда дело заходит о России, ситуация совсем иная. А пренебрежение презумпцией невиновности само по себе является преступлением. Понятно, что такое требование, если еще учесть обозначенные короткие временные рамки, является жестким ультиматумом, цель которого - унизить Россию и очернить ее руководство, что было весьма своевременно аккурат перед выборами президента. Данное требование, учитывая его невыполнимость, можно рассмотреть как повод представить российские власти не стремящимися договариваться, а желающими жестким путем гнуть свою линию, 
невзирая ни на интересы других стран, ни на международное право. Хотя именно Британия демонстрирует свою недоговороспособность — ведь она вместо российских требований провести расследование продолжила навешивать ярлыки на Россию.

Власти Альбиона решили выслать российских дипломатов, прервать дипломатические контакты с Россией, ужесточить санкции, начать борьбу с находящимся на территории Британии российским капиталом и призвать к подобным действиям другие страны. И все это - на основании отсутствия сомнений в причастности РФ к отравлению. Но «не сомневаться» мало, следует предоставить факты, развеивающие сомнения. Тут уместно привести высказанную М. Г. Делягиным в передаче «Комсомольской правды» шутку о том, что не Скрипаля отравили газом «Новичок», а британскую элиту газом «Дурачок». Весьма изящно над логикой обвинителей пошутил А. А. Вассерман: «...если в яд входят элементы из периодической системы Менделеева, а Менделеев - русский, то русские и виноваты. Сутки на оправдания! Ответа нет? Значит, вы и убили-с!» (Вассерман, 2018b: Электронный ресурс).

Мы видим, что история повторяется, когда обращаем свой взор к делу отравленного во все той же Великобритании А. В. Литвиненко. Его отравление и смерть так и остались туманными, в британской (естественно, антироссийской) версии наблюдались серьезные несостыковки, и никаких четких доказательств предоставлено не было. Но обвинили все равно русских. Согласно вердикту, он был отравлен полонием. Объяснялось, что у отравленного полонием выпадают волосы; но на предоставленной фотографии голова Литвиненко лишена волос (тщательно выбрита), зато волосы на груди остались невредимыми. До сих пор в расследовании (если таковое вообще имело место) его смерти не поставлена точка. Так, не существует свидетельства о смерти Литвиненко. Просто если окончательно решить вопрос, возникнет масса претензий к британской стороне. Вердикт об отравлении полонием вызовет вопросы о расхождениях. Вердикт о том, что Литвиненко был отравлен иным веществом, сразу же вызовет вопросы (например, «Вы все это время нас водили за нос и откровенно лгали, и стоит ли вам верить теперь?»). Поэтому не в интересах Альбиона ставить точку как в «деле Литвиненко», так в «деле Скрипалей».

Расследование убийства А. В. Литвиненко не было проведено должным образом, поскольку официально принятая версия не разрешает возникших противоречий; она просто их замалчивает. Также не была раскрыта причина смерти Б. А. Березовского. Аналогичные слова можно сказать в отношении расследования снайперского огня на киевском Майдане и теракта против малазийского Boeing рейса МН17. Скорее всего, расследование отравления Скрипаля тоже не будет доведено до завершения. Похоже, действительно объективное и беспристрастное рассмотрение всех этих дел приведет к вине той стороны, которая активно обвиняет Россию.

Предположим, что действительно российские спецслужбы стоят за 
«делом Скрипаля». Возникает резонный вопрос: зачем им нужно было травить этого перебежчика непосредственно перед президентскими выборами? Российским властям было совершенно невыгодно инициировать такой скандал в этот важный политический момент.

А вот Британии в частности и русофобствующим элитам Запада в целом этот скандал необходим. Он позволяет в очередной раз бросить камень в Россию как перестающего быть послушным актора, замарать ее еще одним мазком грязи и вместе с тем продлить, а то и ужесточить санкции. Ведь в деле дискредитации России (точнее, псевдодискредитации, представляемой в качестве дискредитации) необходима новая кровь, требуется постоянно подбрасывать дополнительные домыслы в виде проверенных фактов. Недостаточно из года в год говорить о вине России в аннексии Крыма, в агрессии против малазийского самолета и прочем. Нужно снова и снова подкидывать в эту топку русофобии новые дрова. Также «дело Скрипаля» - возможность отвести внимание западных (в первую очередь британских) обывателей от социальных и экономических проблем в их странах в сторону России, которую, кстати, можно обвинить заодно в массе внутренних неурядиц Запада. Вместе с тем это повод для дискредитации российской власти накануне выборов и, возможно, для непризнания итогов выборов в дальнейшем.

Еще одно основание для раскрученного скандала — тяжелый выход из ЕС Великобритании, который связан с негодованием континентальной Европы по отношению к Туманному Альбиону и напряженностью в отношениях между Великобританией и ЕС. «Дело Скрипаля» (и другие связанные с Россией громкие дела) могло послужить пусть слабым, но все-таки поводом для нейтрализации напряженности в Европе, сплачивающим фактором западных стран против России. И действительно Брюссель выразил солидарность с Лондоном, решив отозвать посла Евросоюза из России. Заодно лидеры стран ЕС договорились активизировать сотрудничество с НАТО по гражданской обороне, а именно защите от химического, бактериологического и радиологического оружия, а вместе с тем противодействию гибридным вызовам. В итоговом заявлении было отмечено, что «саммит ЕС в самой категорической форме осуждает недавнюю атаку в Солсбери, выражает глубочайшие соболезнования всем тем, чьи жизни подверглись риску, и предлагает помощь в расследовании инцидента. Саммит ЕС чрезвычайно серьезно воспринимает оценку правительства Соединенного Королевства, что ответственность с высокой вероятностью несет РФ и нет альтернативного правдоподобного объяснения» (цит. по: Арутюнян, 2018: Электронный ресурс). Саммит ЕС чрезвычайно серьезно воспринял чрезвычайно несерьезную оценку Соединенного Королевства. Конечно, фраза «нет альтернативного правдоподобного объяснения» является экзотическим вывертом сознания; ведь если считать лондонские нападки на Москву правдоподобным объяснением, то непонятно, что же следует квалифицировать в качестве неправдоподобного.

Получается, любое брошенное обвинение, если оно исходит от сильных мира сего, является правдоподобным просто потому, что его инициато- 
ры - субъекты, которым трудно отказать. Выходит, Лондон может обвинить Москву в отравлении и смерти любого человека, не утруждая себя в доказательной базе, а «цивилизованному» миру будет этого достаточно, чтобы проникнуться эмпатией к обвинителю и реализовать эту эмпатию в реальных действиях. Ситуация не заставила себя долго ждать: страны, входящие в «мировое сообщество», заговорили о необходимости высылки российских дипломатов. Европейские лидеры и те, которые считают себя европейскими, с разной степенью покорности к Лондону и Вашингтону принялись за «святое» дело высылки дипломатов РФ. Ведь сложно проявить непокорность, трудно сказать решительное «нет» царице морей и постоянно солидарному с ней мировому гегемону.

Как обычно, крайне по-холуйски повела себя Украина. До этого ее политики, понимая, что выдворение российских дипломатов вызовет зеркальную реакцию, говорили, будто украинские дипломаты в России защищают права несправедливо осужденных в РФ украинцев. Конечно, под несправедливо осужденными понимались все те, кто действительно совершал преступления. Просто по логике архитекторов Майдана любой признанный виновным российским судом украинец невиновен. Но стоило только США солидаризироваться с лондонским обвинением и заявить о своем решении выслать российских госслужащих, Украина тут же забыла, что ее дипломаты должны защищать права осужденных в РФ украинцев, и присоединилась к высылке российских дипломатических служащих (Вассерман, 2018а: Электронный ресурс). Можно сколько угодно бросаться пафосными фразами о независимости и национальных интересах, но интерес Вашингтона превыше всего. Очевидно, что пес не может ослушаться хозяина, но хотя бы хвостом вилял поменьше.

Очередная выгода этого скандала видится в возможности дальнейшей дискредитации России по сирийскому вопросу. Так, на основании «факта» вины РФ в отравлении Скрипалей может быть раскручен «факт» того, что в Сирии российская сторона причастна к химическим атакам против мирных жителей. И, конечно, в западной прессе не будет идти речь о более правдивом объяснении химатак - о том, что США спонсируют ИГИЛ, боевики которого осуществляют химические атаки, чтобы впоследствии имелась возможность показать в сторону Б. Асада и поддерживающего его В. В. Путина как на непосредственных виновников отравления мирного населения. Т. е. на основе одного недоказанного обвинения можно построить еще одно аналогичное странное обвинение в сторону одного и того же объекта, что нередко и делается. Мол, они отравили Скрипалей, и ничего удивительного нет в том, что теперь они травят сирийцев, почерк ведь один.

Цепочка обвинения, состоящая из ряда необоснованных фактов, которые подаются в виде обоснованных, проявила себя в полной неприглядности. Лондон представил презентацию, и именно она, по словам посла США в России Джона Хантсмана, сподвигла союзников Великобритании в знак солидарности выслать дипломатов РФ. Презентация повторяет уже высказанные 
ранее тезисы, но Россия в ней из категории «с высокой долей вероятности» виновных в отравлении Скрипалей переведена в категорию «виновных без малейшего сомнения» (Коростиков, 2018: Электронный ресурс). Здесь мы видим манипулятивную подвижку, когда сначала возлагают вину в мягкой форме (со словами «скорее всего», «наверняка» и т. д.), постоянно педалируя тему, а потом, когда общественное мнение уже подготовлено, можно перевести «наверняка» в «совершенно точно». Это элемент концепции окна Овертона.

В презентации описываются инциденты, которые Лондон причисляет к враждебным действиям со стороны России. К ним относятся «убийство в 2006 г. Александра Литвиненко», DDoS-атаки на интернет-ресурсы Эстонии в 2007 г., «вторжение в Грузию», «оккупация Крыма», «дестабилизация Украины», сбитый «Боинг» МН-17, «взлом Бундестага», «вмешательство в выборы в США», «попытка организации переворота в Черногории», «кибератака на датское Министерство обороны» и «атака с помощью вирусавымогателя NotPetya». Проблема только в том, что российская вина за эти инциденты не была доказана. Но общественному мнению это знать необязательно. Достаточно просто продуцировать все больше и больше обвинений и убедительность каждого нового подкреплять целым веером предыдущих необоснованных нападок. Ведь в широких СМИ не ставится вопрос на тему, виновна или нет Россия в убийстве Литвиненко, попытке госпереворота в Черногории и т. д. Как бы подразумевается очевидный ответ. А если он очевиден, то аналогичным должен быть ответ на вопрос о «деле Скрипалей».

Очевидно, что обвинение России в причастности к отравлению Скрипалей полезно для борьбы против строительства «Северного потока - 2». Одновременно с вышесказанным можно вспомнить, как чиновники Великобритании говорили о бойкоте чемпионата мира по футболу в России. Помимо прочего, раскрученный маховик (равно как и ряд других нападок в сторону России) следует рассматривать в качестве даже не британского, а интернационально-глобалистского послания к российской элите. Мол, если вы будете продолжать прежнюю политику, если вы не желаете признавать наши интересы в качестве императива, если вы поддерживаете внешнеполитический курс Путина, мы будем дальше вас третировать.

Как обвинение в покушении на жизнь Скрипалей, так и все другие безосновательные нападки, являются тактическими шагами для изоляции России во многих отношениях, настраиванию против нее так называемого мирового сообщества с прицелом на полное ослабление РФ, ее новое глобальное ограбление, десуверенизацию и превращение в колонию Запада. Если же этих целей достичь не удастся, непрекращающиеся обвинения России могут сыграть иную роль. Дело в том, что сильные мира сего медленно но верно движут ситуацию к снижению уровня жизни в западных странах. Однако встает проблема объяснения происходящих процессов народам так, чтобы не возникло серьезного сопротивления «снизу». Отчасти это можно сделать, апеллируя к внешнему врагу, который якобы стремится к разрушению запад- 
ного мира. Почему бы не назначить на роль такого врага страну, которую постоянно обвиняют? Наконец, сами перманентные нападки в ее адрес уже делают ее внешним врагом и вредителем в глазах западной общественности. Вряд ли отсылка к проискам внешнего врага при объяснении социальноэкономических неполадок на Западе возымеет серьезный убедительный эффект. Но лучше хоть какое-то обоснование, чем вообще никакого...

В конце марта 2018 г. Г. М. Родченков стал призывать американских конгрессменов к активным действиям против России, причем уже не только в области спорта. Выступил он в закрывающей лицо балаклаве, заявив, что боится за свою жизнь. Сенатор Кори Гарднер продекларировал: «История Родченкова в очередной раз показывает нам, что Кремль пренебрегает международными законами и стандартами. Родченкову приходиться до сих пор бояться за свою жизнь. Даже на встрече с нами он был в лыжной маске, чтобы скрыть свою внешность. Учитывая отравление Сергея Скрипаля в Англии, этот шаг со стороны Григория вполне оправдан. Я очень впечатлен храбростью этого человека» (Родченков встретился ... , 2018: Электронный ресурс; см.: Butler, 2018: Электронный ресурс).

В этой тираде мы видим клевету на клевете, которая клеветой погоняет. Во-первых, апелляцией к отравлению Скрипаля «доказывается» правота другого мифа (возможность убийства Родченкова со стороны российских спецслужб). Кстати, Родченкова могут действительно убить в США, и это будет выгодно американскому истеблишменту, поскольку всю вину снова возложат на Россию, а после настолько раскрученной истории с этим человеком мало у кого возникнут сомнения в российском следе. Если какой-либо приехавший из РФ человек опасается за свою жизнь, это вовсе не доказывает того, что российские силовики ему угрожают. Когда кто-то считает, что пафосное желание Родченкова скрыть свое лицо является убедительным доказательством кремлевской угрозы, следует говорить о серьезном нарушении логики, об умственной усталости. С таким же успехом можно обратить пристальное внимание на любого параноика, который критикует Кремль и боится за себя, и на основе этого выдвинуть даже не гипотезу, а «аргументированную» концепцию о том, что его страхи оправданы. Вот человек сидит, вжавшись в угол, и всячески тревожится зоркого взгляда «кровавой гэбни», и это уже «веский» повод говорить, что российские спецслужбы действительно кровавые и они ему всячески угрожают. А если кто-то боится расправы со стороны Госдепа, тогда тоже следует делать вывод, что Госдеп угрожает этому человеку? Или такой выверт мышления актуален только в контексте разговора о России?

Во-вторых, рассказ Родченкова нисколько не показывает пренебрежение Кремлем международными законами и стандартами. Напротив, сама развязанная против РФ вакханалия в делах как Родченкова, так и Скрипаля, демонстрирует таковое пренебрежение со стороны элит «цивилизованного» мира. Заодно обратим внимание на внеправовую поддержку Стокгольмским судом Нафтогаза в деле против Газпрома. Также следует вспомнить их 
наплевательское отношение к международному праву, когда они разбомбили Югославию, Ирак и Ливию. Впрочем, эмпирических фактов, указывающих, что международные законы и стандарты этими элитами не признаются, очень много, и мы не будем здесь приводить исчерпывающий список. Информаторы действительно нужны правовому обществу, но это должны быть информаторы, а не клеветники, и общество должно являться правовым, а не называющим себя таковым, элиты которого просто плюют на международное право, когда оно оборачивается против их интересов.

В-третьих, странное у Гарднера представление о храбрости. Да, если бы Родченков действительно находился в опасности, если бы его жизнь зависела от решений Москвы, можно было бы вести речь о храбрости. Но нет ничего храброго в измене Родине, которую собственно этот человек и совершил. Можно было бы его считать храбрым в том смысле, что ему действительно угрожает опасность со стороны американцев. Но здесь скорее имеет смысл говорить не о храбрости, а о глупости.

В-четвертых, Родченков вместо борьбы с допингом помог гнусной, клеветнической, псевдоинформационной борьбе с Россией. Борьба с допингом и ряд совершенно неоправданных и ложных обвинений - совсем разные вещи, но об их различиях, похоже, в «уважаемой» западной среде вспоминать не принято. Равно как не принято там анализировать информацию, подходить к сведениям аналитически, акцентировать внимание на противоречиях и логических неувязках. Вместо этого там принято конструировать эти самые противоречия и логические несоответствия, расширять поле ложной обвинительности в адрес не того, кто виновен в преступлениях, а того, кто виновен в несогласии с мнением Запада.

Реакция российских властей на «дело Скрипалей» довольно слабая. На высылку двадцати трех наших дипломатов из Великобритании следует реагировать высылкой гораздо большего количества британских подданных из РФ. Важно поставить вопрос о прекращении отправки газа в Туманный Альбион. Может быть, в таких случаях стоит задуматься о разрыве дипломатических отношений. Поскольку дочь Скрипаля является гражданкой РФ, необходимо было обставить ситуацию так, чтобы не Британия заставляла РФ объясняться и оправдываться, а происходил ровно обратный процесс. Оправдания создают психологическую убежденность в виновности. Скрипалей нам так и не предъявили, из чего следует вывод, что гражданка РФ была похищена. Следовательно, необходимо использовать все инструменты, чтобы обвинить наших британских «коллег» в похищении российского подданного. Целесообразно бомбардировать британцев требованиями объяснить, как они допускают отравление на своей территории гражданки России, вопросами о том, почему так плохо работают их специальные службы, отвечающие за безопасность. Особенно важно постоянно ставить их перед лицом неудобных вопросов, апеллирующих к обнаженности всей доказательной базы. За необоснованное, очевидно, клеветническое, связанное с нарушениями Конвенции о запрещении химического оружия обвинение тоже нужно платить. Но 
российская элита, кажется, не готова достаточно обстоятельно и последовательно отстаивать интересы страны.

Вообще, наша элита обычно очень неохотно реагирует контрсанкциями на очевидные враждебные, да еще и основанные на подтасовках и лжи акции против нашей страны. Можно сказать, такая псевдореакция стала традицией среди российских властей, от которой требуется отказываться. России нужно вместо отправления слезливых нот протеста отвечать более чем зеркально на голословные обвинения и следующее за ними наглое давление, сопряженное с соответствующими действиями. Отвечать надо сильно, ассиметрично, чтобы российская реакция перекрывала мощь антироссийской акции, и геополитический оппонент понимал, что имеет дело вовсе не с напуганным ребенком, вызванным на ковер. Важно, чтобы он осознавал простую истину: его действия вызовут реакцию, крайне невыгодную для него же. Когда мы отвечаем слабо или вообще проглатываем недружественные акции как должное, этим даем понять миру, что нас позволительно унижать (вспоминается строка из песни Е. Летова: «Собрав всю волю воедино, умело подави толчок»). Аналогичная ситуация возникает и тогда, когда наше руководство вместо самостоятельного формирования повестки дня всего лишь отвечает на повестку, сформированную за пределами России и настроенную против России.

В конце концов британцы, так и не обосновав свои нападки, благополучно ушли с темы Скрипалей. Как говорится, просто слились. Но спустя несколько месяцев тема снова стала набирать ход; британцы объявили имена граждан России, якобы виновных в отравлении Скрипалей. Однако и это объявление не добавило доказательности делу. Ведь не была обоснована их вина, а британское правительство отказалось поделиться с Россией отпечатками пальцев обвиняемых. «Правительству очевидно, что эти люди - офицеры российской военной разведки, ГРУ, и что они использовали чрезвычайно токсичное незаконное химоружие на улицах нашей страны» (Табак, 2018: Электронный ресурс), — заявил представитель МИД Великобритании. Однако что значит «очевидно»? Как что-то может быть очевидно без конкретных улик? С таким же успехом любой может сказать слово «очевидно», после которого завести абсолютно бредовую речь о виновности кого-либо в чем-либо. Альбион остался верен подходу «У нас есть все улики, но делиться ими не будем».

Сделаем небольшое культурологическое отступление. Ситуация со Скрипалем, равно как и множество других антироссийских обвинений и действий со стороны Запада, доказывает в очередной раз несколько важных межкультурных различий. У русских нет понятия абсолютного зла, единственный вариант взаимодействия с которым - его полное истребление (или по крайней мере отсутствие взаимодействия как такового). В русских сказках даже со злыми персонажами главный герой пытается договориться. Поэтому мы наивно пытаемся договариваться с теми, с кем почти невозможно это сделать. Если мы думаем, что со всеми можно найти компромисс, это не значит, что абсолютно все готовы с нами договариваться. Иногда мы не видим в 
человеке того, кем он является - заведомого обманщика, и нам кажется, что он будет нас обманывать лишь до определенного предела, что есть мера, через которую переступать недопустимо. Однако некоторые другие культуры действуют по совсем иным принципам. Если русская культура ориентируется на Правду, которая понимается в качестве объективного явления, то западная (преимущественно англосаксонская культура) под правдой понимает то, что лично выгодно. То есть невыгодное, не приносящее пользу представляется в качестве скверны. Неудивительно, что именно у англосаксов получило широкое признание такое философское направление, как прагматизм. Вполне объяснимо, что сегодня они используют бездоказательные, но выгодные для себя обвинения в адрес оппонентов. Также в русской культуре наличествует идея справедливости, поэтому даже нашим олигархам трудно понять, почему англосаксы начали наступление на их деньги - ведь эти олигархи перевели финансы из ограбленной ими России в ту же Британию, и последняя должна быть им благодарна. Им сложно осознать, что на самом деле британцы ничего им не должны; когда речь идет о личной выгоде, справедливость становится вторичной. У русского человека с трудом укладывается в голове мысль типа «Я ему сделаю добро, а он мне без зазрения совести ответит злом», причем абсолютным злом, т. е. отнимет не часть собственности, а всю.

В качестве дополнительного примера можно привести описание наиболее приемлемого выхода из конфликта в российских и англосаксонских учебниках по конфликтологии. Отечественные авторы говорят о необходимости учитывать мнение оппонента, решать проблему с учетом этого мнения и приходить к компромиссу, т. е. к взаимоприемлемому решению. Англосаксонские авторы пропагандируют принцип выигрыша любой ценой, подразумевая, что при компромиссе конфликтант достигает положительного эффекта для себя, но при этом такое разрешение конфликта указывает на проявление им недостаточного переговорного профессионализма: ведь он недожал оппонента, недоработал, не смог достичь максимальной выгоды.

Британские и американские политики по достоинству заслуживают звания не демократических мессий, несущих свет правды, свободы и цивилизации в мир, а наиболее аморальных мошенников, которые постоянно использовали хитрость, инсинуации и обман для саморекламы, дискредитации противника и поддержания своей гегемонии. Раздача обещаний и их невыполнение - обычный конек мистеров и сэров. Так, в 2018 г. Великобритания объявила о своем решении отказаться от признания российских дипломов. Подобное решение может высказать не только Туманный Альбион, но и любая другая (или другие) страна «цивилизованного» мира. Выходит, разговоры о признании российских дипломов были лживыми, и переход России на болонские рельсы в образовании не дает никаких гарантий того, что наши образованные люди будут цениться за рубежом.

Теперь обратимся в еще дальнее нелицеприятное прошлое джентльменов, заглянув в книгу Ф. У. Энгдаля. Премьер Британии Б. Дизраэли в ходе Берлинского конгресса 1878 г. обещал туркам поддержать Османскую импе- 
рию в ее территориальных претензиях на Балканском полуострове. В обмен Британия получила контроль над стратегически важным Кипром, но свое обещание нарушила. В 1882 г. британцы сообщили туркам о решении послать свои войска в Египет, чтобы подавить поднятый военными офицерами мятеж и восстановить порядок и подчинение Константинополю. Разгромив революционеров, британцы оккупировали Египет и получили контроль над стратегически важным Суэцким каналом; в результате эти территории фактически из юрисдикции обманутого османского султана перешли к Британской империи.

Британцы позже обманули соперников Османской империи. Предводителю антиосманского восстания Хусейну они пообещали одобрение провозглашения Арабского исламского халифата, если тот поддержит Британию против Османской империи. Но британцы также сулили власть над Аравией конкуренту Хусейна — вождю племён бедуинов Абдуле-Азиз ибн Сауду, которого тоже хотели использовать в войне против османов. По сути это была война чужими руками. Невзирая на обещания арабским врагам Османской империи, британцы заключили соглашение с Францией и Россией о разделе арабских территорий. В итоге секретный британо-французский пакт СайксаПико о разделе Ближнего Востока стал предательством Великобританией данных своим арабским союзникам обещаний. При разделе между странамипобедительницами территории поверженного противника Россия тоже была кинута англичанами, которые обманным путем получили арабских территорий больше всех (Энгдаль, 2016).

\section{ОТ ИНФОРМАЦИОННОГО ОБЩЕСТВА - $К$ ПСЕВДОИНФОРМАЦИОННОМУ}

В последние годы очень много пишут про информационное общество как социальную реальность настоящего времени. Однако более верным было бы назвать современное социальное состояние скорее псевдоинформационным, так как поле сообщений насыщено когнитивными противоречиями, знанием и псевдознанием, истинами и мифами, информацией и псевдоинформационным спамом. Антропное пространство наполнилось и постоянно наполняется огромным количеством сообщений, в океане которых все труднее отличить ложное от действительного, значимое от второстепенного. Важная проблема современной реальности состоит не только в перенасыщенности псевдоинформацией, но в отсутствии четких критериев отделения истины от лжи, полезных сообщений от вредных. Критерии, демаркационные линии утопают в бескрайнем океане сведений (более подробно о проблемах знания и псевдознания в информационном обществе см.: Ильин, 2012: Электронный ресурс).

Сами условия современного так называемого информационного мира стимулируют трансформации сознания. Нарастает вес информационных технологий, которые где-то описывают реальность, а где-то ее подменяют. Продукт функционирования информационных технологий в основном представ- 
ляет собой псевдоинформационный спам, который во многом сопряжен не с отражением реальности, а с ее фальсифицированием или откровенной ложью и манипулированием. Поэтому сами эти технологии далеко не всегда оправдывают свое название как «информационные». Их продукт, даже если он в корне не соответствует реальности, все-таки ее усложняет, становится ее элементом с точки зрения реципиентов, не способных отделить в этом массиве те сведения, которые реалистичны, от тех, которые манипуляционны и лживы. Когда же мы действуем в реальности на основе ложной, не согласующейся с реальностью картиной мира, мы все равно, несмотря на данное расхождение, вносим свой вклад в изменение реальности. Только результат обычно сильно отличается от желаемого. Вполне ожидаемо, что типичный западный зритель воспринимает на веру содержание того контента, которым бомбардируют его сознание.

Одни новости, призывы и лозунги активно замещаются другими, одна риторика «наползает» на предыдущую, новые возгласы заставляют своих предшественников уйти в сторону. Любое здравое, рациональное, нравственно состоятельное, социально полезное высказывание просто тонет в этом потоке. «Белый шум» делает свое дело... СМИ переполняют совершенно ненужные и бесполезные сведения. Интеллектуально ущербные ток-шоу заполонили собой медиапространство. Они тиражируют «информацию» о том, кто на ком женился, кто с кем развелся, кто себя повел в эпатажной манере, кто с кем переспал и т. д. Реклама постоянно говорит о моде, о редко необходимых вещах, о том, что они приносят счастье и успех. Действительно важные сведения утопают в этом потоке бессмысленности, мелкотемья, манипуляций сознанием и прямой лжи. Строгие запреты не нужны, поскольку запретный плод сладок, а в социуме рождается убеждение, что запретное есть истинное. Помимо этого, объект запрещения становится понятен и явственен, обществу известно, какие мнения и точки зрения невыгодны тем, кто управляет медиасферой. Самим же магнатом медиа (и западного мира в целом) невыгодно, чтобы широкие массы были знакомы с «неправильным» дискурсом. Перенасыщение, в котором тонет истина, эффективней прямых запретов.

В современных условиях засилья псевдоинформационного спама и причудливого переплетения информации и дезинформации у среднестатистического реципиента иссякают шансы отделить правду от лжи. У него нет ни времени, ни возможности самостоятельно докопаться до истины, рассмотреть различные источники, альтернативные версии. Сама реальность выступает помехой. А если - в дополнение к этому - образовательные системы отказываются формировать строгое методологическое мышление и демонстрируют свою когнитивную бедность (что происходит как на Западе, так и - в меньшей степени - в России), это создает еще большую проблему верификации поступающих сведений. Не слишком наученный критически мыслить человек, привыкший к потреблению самых примитивных продуктов массовой культуры, да еще с перегруженным всякой псевдоинформацией мозгом, будет сопротивляться восприятию и пониманию того, что требует 
внутреннего напряжения, интеллектуальных усилий. Остается только пассивно и молчаливо принимать на веру не то сообщение, которое логически и фактологически обосновано, а то, которое выделяется из «белого шума», постоянно демонстрируется во всех «передовых» СМИ и многократно повторяется, будучи продуктом жутко идеологизированного «дискурса воображаемого».

Ведь «белый шум» захватывает далеко не все псевдоинформационное поле. В бескрайнем океане сведений остается защищенным от утопления контент, который тиражируется ведущими СМИ, продвигающими интересы политико-экономической верхушки. Он как бы стоит над схваткой. Этот контент представляется его создателями основным (и потому неутопающим), который должен в идеале совершить интервенцию в ментальное пространство каждого реципиента и формировать общественные настроения.

Описанные медийные явления мы наблюдаем в России, в которой власть имущие тоже используют СМИ как средство управления мыслями людей, а значит, их действиями. Данной теме можно посвятить отдельное исследование, но нас интересует в рамках настоящей работы несколько иное то, что эти тенденции, проявляя себя на Западе, формируют соответствующий спектр мнений у людей о различных мировых явлениях, процессах, странах. «Белый шум» отвлекает реципиентов от реальных проблем их обществ, вводит в дискурс беззаботной развлекательности, снижает их политически активный (оппозиционный) потенциал. Одновременно «сверху» псевдоинформационного массива с помощью манипуляций и прямой лжи насаждается «нужная» идеологическая составляющая, которая говорит о многом в том числе о том, что Россия виновата во всем, в чем только ее можно и нельзя обвинить. Медийная политика делает так, чтобы политическая риторика воспринималась как единственная заслуживающая внимания, как единственно объективная и объясняющая суть происходящих событий. В свою очередь, сфера политического нарратива как более широкое явление может полниться необоснованными и лживыми догмами, но должна выглядеть целостной, не имеющей складок и трещин, конкурентоспособных по отношению к главенствующей риторике альтернативных дискурсов, показывающих слабые места и/или откровенную необоснованность доминирующего типа наррации. Когда не представлены альтернативные версии, и при этом «правильная» позиция навязывается с особой тщательностью и повторяемостью, она начинает казаться аргументированной. Продуктами данных тенденций являются «правильное» (на самом деле ложное) сознание масс, идеологическое наполнение ментального пространства большинства, отданные за нужную политическую силу голоса.

Здесь уместно привести слова Г. Лебона: «...часто повторяемая идея, в конце концов, врезается в самые глубокие области бессознательного, где именно и вырабатываются двигатели наших поступков. Спустя некоторое время мы забываем, кто был автором утверждения, повторявшегося столько раз, и, в конце концов, начинаем верить ему, отсюда-то и происходит изуми- 
тельное влияние всяких публикаций. После того, как мы сто, тысячу раз прочли, что лучший шоколад - это шоколад $\mathrm{X}$, нам начинает казаться, что мы слышали это с разных сторон, и мы, в конце концов, совершенно убеждаемся в этом. Прочтя тысячи раз, что мука V спасла таких-то и таких-то знаменитых людей от самой упорной болезни, мы начинаем испытывать желание прибегнуть к этому средству, лишь только заболеваем аналогичной болезнью. Читая постоянно в одной и той же газете, что А - совершенный негодяй, а В - честнейший человек, мы, в конце концов, становимся сами, убежденными в этом, конечно, если только не читаем при этом еще какую-нибудь другую газету, высказывающую совершенно противоположное мнение. Только утверждение и повторение в состоянии состязаться друг с другом, так как обладают в этом случае одинаковой силой» (Лебон, 1998: 198).

Неудивительно, что американцы в свое время поверили крайне лживой риторике о связи С. Хусейна с «Аль-Каидой» и о наличии в Ираке оружия массового поражения. Самым известным случаем «обоснования» антииракского нарратива является выступление в ООН госсекретаря К. Пауэлла. Он произнес пламенную и совершенно бездоказательную речь о злобном Саддаме и усиленно тряс пробиркой с непонятным веществом, приговаривая, что это - доказательство вины Хусейна. Содержимое пробирки могло быть чем угодно; например, стиральным порошком. Демонстрация пробирки была задумана как веское основание, камня на камне не оставляющее от альтернативной версии. Это позиционировалось как весомый аргумент, который должен развеять все сомнения. Американцы разбомбили Ирак, но химического оружия не нашли. Их ошибка стоила очень дорого миллионам иракцев. А ошибка ли? Так может, и обвинения России в отравлениях людей — аналогичная ошибка? Как заметили О. Стоун и П. Кузник, после данного «убедительного» выступления госсекретаря войну поддерживала уже не треть, а половина всего населения США; сам же Пауэлл позже вспомнит это событие как недостойную страницу своей карьеры (Стоун, Кузник, 2014). Для нас здесь важен простой факт: совершенно необоснованное, клоунское выступление вкупе с аналогичными вызвало такой массовый милитаристский эффект.

Можно услышать множество разговоров о том, что информационная революция создаст просвещенное общество, способное охватывать вниманием основные события и выносить информированное суждение по всем важным вопросам. Однако так называемый переход к информационному обществу вовсе не повышает уровень общественного сознания.

\section{ЗАКЛЮЧЕНИЕ}

Фактором национальной безопасности является не только политика, но и культура. Российская культура во многом проникнута западным влиянием - и не всегда тем, которое обогащает нашу страну чем-то действительно полезным. Происходит «обогащение» русского языка англицизмами. Консюмеристское сознание россиян следует в фарватере построенной на Западе инду- 
стрии моды. До сих пор мы преклоняемся перед культурой нашего цивилизационного оппонента, считая ее чем-то особенно высоким. Даже идущие оттуда русофобские интенции определенный сегмент россиян воспринимает за истину в последней инстанции. Во многом мы подражаем западным веяниям в самых разных аспектах культурной жизни.

Любые заимствования должны быть тщательно отрефлектированы, чтобы можно было отделять полезное от вредного, необходимое от ненужного. И уж тем более если Россия будет продолжать интегрировать культурные веяния другой цивилизации, существенно вырастут риски утраты своего культурного наследия, а значит, и важнейшего фактора национальной безопасности. В геополитической борьбе побеждают не только сильные в экономическом и военном смысле народы. Сохранение себя невозможно без сохранения собственной культуры, гордости за национальную принадлежность, здорового патриотизма. Для этого следует как минимум адекватно реагировать на антироссийские выпадки, совершаемые западным миром, и помнить о подлинных мотивах их нападок. Мнение этого культурно-цивилизационного региона далеко не всегда является объективным, обоснованным и достойным уважения.

\section{СПИСОК ЛИТЕРАТУРЫ}

Алексеев, А. Б. (2018) Политический миф как средство ведения современной информационной войны // Информационные войны как борьба геополитических противников, цивилизаций и различных этосов : сб. трудов Всерос. науч. конф. (г. Новосибирск, 26-27 апреля 2018 г.) / под науч. ред. проф. В. Ш. Сабирова. Новосибирск : СибГУТИ. 820 с. С. 11-18.

Арутюнян, А. (2018) ЕС отзывает посла в России в связи с делом Скрипаля [Электронный ресурс] // TACC. 23 марта. URL: http://tass.ru/mezhdunarodnaya-panorama/5058252 [архивировано в WaybackMachine] (дата обращения: 02.10.2018).

В СБ ООН заблокирован российский проект заявления по делу Скрипаля (2018) [Электронный ресурс] // Российская газета. 15 марта. URL: https://rg.ru/2018/03/15/v-sb-oon-zablokirovan-rossijskij-proekt-zaiavleniia-po-delu-skripalia.html [архивировано в WaybackMachine] (дата обращения: 22.08. 2018).

Вассерман, А. А. (2017) В надежде раскачать Россию [Электронный ресурс] // PEH TВ. 8 декабря. URL: http://ren.tv/blog/253608 [архивировано в WaybackMachine] (дата обращения: 18.08.2018).

Вассерман, А. А. (2018а) Открытым текстом 30.03.2018 [Электронный pecypc] // Вассерман Анатолий Александрович. 31 марта. URL: http:// vassermans.ru/otkrytym-tekstom/otkrytym-tekstom-30-03-2018/ [архивировано в WaybackMachine] (дата обращения: 12.03.2018).

Вассерман, А. А. (2018b) Открытым текстом 16.03.2018 [Электронный pecypc] // Вассерман Анатолий Александрович. 18 марта. URL: http://vassermans.ru/otkrytym-tekstom/otkrytym-tekstom-16-03-2018/ [архивировано в 
WaybackMachine] (дата обращения: 24.03.2018).

Вассерман, А. А. (2018c) Открытым текстом 20.04.2018 [Электронный pecypc] // Вассерман Анатолий Александрович. 20 апреля. URL: https://vassermans.ru/otkrytym-tekstom/otkrytym-tekstom-20-04-2018/ [архивировано в WaybackMachine] (дата обращения: 18.05.2018).

Глава ЦРУ заявил, что Россия десятилетиями вмешивается в выборы в США (2018) [Электронный ресурс] // HTB. 8 января. URL: http://ntv.ru/ novosti/1969280/ [архивировано в WaybackMachine] (дата обращения: 26.08. 2018).

Голованов, Р. (2016) Украинских националистов попытались выдать за российских болельщиков [Электронный ресурс] // Комсомольская правда. 14 июня. URL: https://www.kp.ru/daily/26541/3558622/ [архивировано в WaybackMachine] (дата обращения: 18.09.2018).

Грешневиков, А. Н. (2003) Эра экологического апокалипсиса. М. : Жизнь и мысль. 591 с.

Дугин, А. Г. (2011) Геополитическое будущее России: многополярность и основные стратегические перспективы в XXI в. // Вестник Московского университета. Серия 18: Социология и политология. № 2. С. 68-97.

Заквасин, А. и др. (2018) «Агрессивная линия вражды»: зачем Лондон пошёл на обострение отношений с Москвой / А. Заквасин, Н. Алексеева, A. Ксенофонтова, И. Оганджанов [Электронный ресурс] // RT на русском. 15 марта. URL: https://russian.rt.com/world/article/491869-velikobritaniya-diplomati-razryv-otnoshenia [архивировано в WaybackMachine] (дата обращения: 07.08.2018).

Ильин, А. Н. (2012) От гиперинформационности к информационному потребительству [Электронный ресурс] // Информационный гуманитарный портал «Знание. Понимание. Умение». № 6 (ноябрь - декабрь). URL: http://www.zpu-journal.ru/e-zpu/2012/6/Ilyin_Hyperinformationality-InformationConsumerism/ [архивировано в WaybackMachine] (дата обращения: 18.08. 2018).

Ильин, А. Н. (2017а) США: безответственная риторика и вероломная политика [Электронный ресурс] // Горизонты гуманитарного знания. № 5. С. 48-70. URL: http://journals.mosgu.ru/ggz/article/view/602 (дата обращения: 18.10.2018). DOI: $10.17805 /$ ggz.2017.5.5

Ильин, А. Н. (2017b) Френсис Фукуяма: ради идеологически нагруженной русофобии все средства хороши [Электронный ресурс] // Горизонты гуманитарного знания. № 2. C. 40-54. URL: http://journals.mosgu.ru/ggz/ article/view/461 (дата обращения: 20.10.2018). DOI: 10.17805/ggz.2017.2.4

Ильин, А. Н. (2018а) Антиинформационная риторика Соединенных Штатов Америки в условиях информационной войны // Ученые записки Комсомольского-на-Амуре государственного технического университета. Науки о человеке, обществе и культуре. Т. 2. № 1 (33). С. 34-42.

Ильин, А. Н. (2018b) Бжезинский об Украине // Свободная мысль. № 1 (1667). C. 155-164. 
Ильин, А. Н. (2018с) Русофобия / предисл. Н. Старикова. СПб. : Питер. $320 \mathrm{c}$.

Коломиец, М. (2016) Главред «Эха Москвы» Венедиктов возглавил армию «фейкометов» на Евро-2016 [Электронный ресурс] // Ридиус. 13 июня. URL: https://www.ridus.ru/news/223644 [архивировано в WaybackMachine] (дата обращения: 22.09.2018).

Коростиков, М. (2018) Россию заклеймили обзором [Электронный ресурс] // Коммерсант. № 52. 28 марта. C. 6. URL: https://www.kommersant.ru/ doc/3586195 [архивировано в WaybackMachine] (дата обращения: 18.08.2018).

Красько, А. С., Ивкина, П. Ю. (2018) Проблема информационной войны между Западом и Россией на примере «дела Скрипаля» // Информационные войны как борьба геополитических противников, цивилизаций и различных этосов : сб. трудов Всерос. науч. конф. (г. Новосибирск, 26-27 апреля 2018 г.) / под науч. ред. проф. В. Ш. Сабирова. Новосибирск : СибГУТИ. 820 c. С. $352-361$.

Лебон, Г. (1998) Психология толп // Психология толп. М. : Ин-т психологии РАН ; КСП+. 416 с. С. 15-254.

Лэш, К. (2002) Восстание элит и предательство демократии / пер. Дж. Смити, К. Голубович. М. : Логос ; Прогресс. 224 с.

Обзор российских интеллектуальных журналов (2004) / В. Морозов, П. Резвых [Электронный ресурс] // Неприкосновенный запас. № 2 (34). URL: http://magazines.russ.ru/nz/2004/34/zh14.html [архивировано в WaybackMachine] (дата обращения: 12.08.2018).

Родченков встретился с американским правительством и обсудил угрозы для США со стороны России [Электронный pecypc] // Sports.ru. 24 марта. URL: https://www.sports.ru/biathlon/1061584117.html [архивировано в WaybackMachine] (дата обращения: 18.09.2018).

Сикорский, Д. (2016) Полная дегуманизация: европейские СМИ сделали из россиян монстров [Электронный ресурс] // Экономика сегодня. 15 июня. URL: https://rueconomics.ru/179299-polnaya-degumanizaciya-evropeiskiesmi-sdelali-iz-rossiyan-monstrov [архивировано в WaybackMachine] (дата обращения: 28.09.2018).

Стоун, О., Кузник, П. (2014) Нерассказанная история США / пер. с англ. А. Оржицкого, В. Полякова. М. : КоЛибри ; Азбука-Аттикус. 928 с.

Табак, М. (2018) МИД Британии назвал интервью «подозреваемых» по делу Скрипалей лживым [Электронный ресурс] // РИА Новости. 3 сентября. URL: https://ria.ru/world/20180913/1528486685.html [архивировано в Wayback Machine] (дата обращения: 14.09.2018).

Тарасов, А. (2011) Десятилетие позора. Тезисы обвинительной речи [Электронный ресурс] // Интелрос. 23 ноября. URL: http://www.intelros.ru/ subject/figures/aleksandr-tarasov/12113-desyatiletie-pozora-tezisy-obvinitelnoyrechi.html [архивировано в WaybackMachine] (дата обращения: 18.07.2018).

Фахрутдинов, Р. (2018) НАТО разберется: Британия жалуется на отравление шпиона [Электронный ресурс] // Газета.ru. 11 марта. URL: https://www. 
gazeta.ru/social/2018/03/11/11678509.shtml [архивировано в WaybackMachine] (дата обращения: 11.09.2018).

Фуко, М. (2002) О природе человека. Справедливость против власти // Фуко М. Интеллектуалы и власть: Избранные политические статьи, выступления и интервью / пер. с франц. С. Ч. Офертаса под общей ред. В. П. Визгина, Б. М. Скуратова. М. : Праксис. 384 с. С. 81-147. (Новая наука политики).

Фурсов, А. И. (2013) Серые волки и коричневые рейхи. Тайная история послевоенного мира. Статья третья // Свободная мысль. № 4 (1640). С. $183-$ 196.

Шиллер, Г. (1980) Манипуляторы сознанием. М. : Мысль. 326 с.

Энгдаль, Ф. У. (2016) Священные войны Западного мира. М. : Селадо. $336 \mathrm{c}$.

Butler, N. (2018) Rodchenkov meets with members of US Government Agency to discuss Russian doping [Электронный pecypc] // Insidethegames.biz. March 24. URL: https://insidethegames.biz/index.php/articles/1063043/rodchenkov-meets-with-members-of-us-government-agency-to-discuss-russian-doping [apхивировано в WaybackMachine] (дата обращения: 11.09.2018).

Drumbell, J. (1995) The Carter presidency: A re-evaluation. Manchester : Manchester University Press. viii, 235 p.

Дата поступления: 4.10.2018 г.

\section{REFERENCES}

Alekseev, A. B. (2018) Politicheskii mif kak sredstvo vedeniia sovremennoi informatsionnoi voiny [Political myth as a mean of modern information war waging]. In: Informatsionnye voiny kak bor'ba geopoliticheskikh protivnikov, tsivilizatsii i razlichnykh etosov [Information wars as a struggle of geopolitical opponents, civilizations and various ethos] : Proceedings of the All-Russian conference (Novosibirsk, April 26-27, 2018) / ed. by V. S. Sabirov. Novosibirsk : SibSUTIS Publ. 820 p. Pp. 11-18. (In Russ.).

Arutiunian, A. (2018) ES otzyvaet posla v Rossii v sviazi s delom Skripalia [EU withdraws Ambassador to Russia in connection with the case of Skripal]. TASS. March 23. [online] Available at: http://tass.ru/mezhdunarodnaya-panorama/5058252 [archived in WaybackMachine] (accessed 02.10.2018). (In Russ.).

V SB OON zablokirovan rossiiskii proekt zaiavleniia po delu Skripalia [The UN Security Council blocked Russian draft statement regarding the case of Skripal]. (2018) Rossiiskaia gazeta, March 15. [online] Available at: https://rg.ru/2018/03/15/v-sb-oon-zablokirovan-rossijskij-proekt-zaiavleniia-po-delu-skripalia.html [archived in WaybackMachine] (accessed 22.08.2018). (In Russ.).

Wasserman, A. A. (2017) V nadezhde raskachat' Rossiiu [Hoping to destabilize Russia]. REN TV, December 8. [online] Available at: http://ren.tv/blog/253608 [archived in WaybackMachine] (accessed 18.08.2018). (In Russ.).

Wasserman, A. A. (2018a) Otkrytym tekstom 30.03.2018 [Explicitly, 30.03.2018]. Wasserman Anatolii Aleksandrovich, March 31. [online] Available at: 
http://vassermans.ru/otkrytym-tekstom/otkrytym-tekstom-30-03-2018/ [archived in WaybackMachine] (accessed 12.03.2018). (In Russ.).

Wasserman, A. A. (2018b) Otkrytym tekstom 16.03.2018 [Explicitly, 16.03.2018]. Wasserman Anatolii Aleksandrovich, March 18. [online] Available at: http://vassermans.ru/otkrytym-tekstom/otkrytym-tekstom-16-03-2018/ [archived in WaybackMachine] (accessed 24.03.2018). (In Russ.).

Wasserman, A. A. (2018c) Otkrytym tekstom 20.04.2018 [Explicitly, 20.04.2018]. Wasserman Anatolii Aleksandrovich, April 20. [online] Available at: https://vassermans.ru/otkrytym-tekstom/otkrytym-tekstom-20-04-2018/ [archived in WaybackMachine] (accessed 18.05.2018). (In Russ.).

Glava TsRU zaiavil, chto Rossiia desiatiletiiami vmeshivaetsia v vybory $\mathrm{v}$ SShA [The head of the CIA said that Russia had been interfering in U.S. elections for decades] (2018) NTV, January 8. [online] Available at: http://www. ntv.ru/novosti/1969280/ [archived in WaybackMachine] (accessed 26.08.2018). (In Russ.).

Golovanov, R. (2016) Ukrainskikh natsionalistov popytalis' vydat' za rossiiskikh bolel'shchikov [Ukrainian nationalists were disguised as Russian fans]. Komsomol'skaia pravda, June 14. [online] Available at: https://www.kp.ru/ daily/26541/3558622/ [archived in WaybackMachine] (accessed 18.09.2018). (In Russ.).

Greshnevikov, A. N. (2003) Era ekologicheskogo apokalipsisa [The age of ecological apocalypse]. Moscow : Zhizn' i mysl' Publ. 591 p. (In Russ.).

Dugin, A. G. (2011) Geopoliticheskoe budushchee Rossii: mnogopoliarnost' i osnovnye strategicheskie perspektivy v XXI v. [Geopolitical future of Russia: Multipolarity and strategical perspectives in the 21st century]. Vestnik Moskovskogo universiteta. Seriia 18: Sotsiologiia i politologiia, no. 2, pp. 68-97. (In Russ.).

Zakvasin, A. et al. (2018) "Agressivnaia liniia vrazhdy»: zachem London poshel na obostrenie otnoshenii s Moskvoi [“Aggressive line of hatred”: The reason why London contributed to the aggravation of relations with Moscow] / A. Zakvasin, N. Alekseeva, A. Ksenofontova, I. Ogandzhanov. RT na russkom, March 15. [online] Available at: https://russian.rt.com/world/article/491869velikobritaniya-diplomati-razryv-otnoshenia [archived in WaybackMachine] (accessed 07.08.2018). (In Russ.).

Ilyin, A. N. (2012) Ot giperinformatsionnosti k informatsionnomu potrebitel'stvu [From hyperinformationality to information consumerism]. Informatsionnyi gumanitarnyi portal "Znanie. Ponimanie. Umenie", no. 6 (November — December). [online] Available at: http://www.zpu-journal.ru/e-zpu/2012/6/ Ilyin_Hyperinformationality-Information-Consumerism/ [archived in WaybackMachine] (accessed 18.08.2018). (In Russ.).

Ilyin, A. N. (2017a) SShA: bezotvetstvennaia ritorika i verolomnaia politika [The USA: Irresponsible rhetoric and treacherous policy]. Gorizonty gumanitarnogo znaniia, no. 5, pp. 48-70. [online] Available at: http://journals.mosgu.ru/ggz/ article/view/602 (accessed 18.10.2018). (In Russ.). DOI: 10.17805/ggz.2017.5.5 
Ilyin, A. N. (2017b) Frensis Fukuiama: radi ideologicheski nagruzhennoi rusofobii vse sredstva khoroshi [Francis Fukuyama: For the sake of ideologically loaded russophobia by all means]. Gorizonty gumanitarnogo znaniia, no. 2, pp. 40-54. [online] Available at: http://journals.mosgu.ru/ggz/article/view/461 (accessed 20.10.2018). (In Russ.). DOI: 10.17805/ggz.2017.2.4

Ilyin, A. N. (2018a) Antiinformatsionnaia ritorika Soedinennykh Shtatov Ameriki $\mathrm{v}$ usloviiakh informatsionnoi voiny [Anti-information rhetoric of the United States in the information war]. Uchenye zapiski Komsomol'skogo-na-Amure gosudarstvennogo tekhnicheskogo universiteta. Nauki o cheloveke, obshchestve i kul'ture, vol. 2, no. 1 (33), pp. 34-42. (In Russ.).

Ilyin, A. N. (2018b) Bzhezinskii ob Ukraine [Brzezinski about Ukraine]. Svobodnaia mysl', no. 1 (1667), pp. 155-164. (In Russ.).

Ilyin, A. N. (2018c) Rusofobiia [Russophobia] / foreword by N. Starikov. St. Petersburg : Piter Publ. 320 p. (In Russ.).

Kolomiets, M. (2016) Glavred «Ekha Moskvy» Venediktov vozglavil armiiu «feikometov» na Evro-2016 [Chief editor of "Echo of Moscow" Venediktov took the lead of the army of "fake throwers" at the Euro 2016]. Ridius, June 13. [online] Available at: https://www.ridus.ru/news/223644 [archived in WaybackMachine] (accessed 22.09.2018). (In Russ.).

Korostikov, M. (2018) Rossiiu zakleimili obzorom [Russia has been accused in a review]. Kommersant, no. 52, March 28, p. 6. [online] Available at: https://www.kommersant.ru/doc/3586195 [archived in WaybackMachine] (accessed 18.08.2018). (In Russ.).

Kras'ko, A. S. and Ivkina, P. Yu. (2018) Problema informatsionnoi voiny mezhdu Zapadom i Rossiei na primere «dela Skripalia» [The issue of the information war between the West and Russia: A study of the "case of Skripal”]. In: Informatsionnye voiny kak bor'ba geopoliticheskikh protivnikov, tsivilizatsii $i$ razlichnykh etosov [Information wars as a struggle of geopolitical opponents, civilizations and various ethoses] : Proceedings of the All-Russian conference (Novosibirsk, April 26-27, 2018) / ed. by V. S. Sabirov. Novosibirsk : SibSUTIS Publ. 820 p. Pp. 352-361. (In Russ.).

Le Bon, G. (1998) Psikhologiia tolp [The psychology of crowds]. In: Psikhologiia tolp [The psychology of crowds]. Moscow : Institute of Psychology RAS ; KSP+ Publ. 416 p. Pp. 15-254. (In Russ.).

Lasch, C. (2002) Vosstanie elit i predatel'stvo demokratii [The revolt of the elites and the betrayal of democracy] / transl. by J. Smiti and K. Golubovich. Moscow : Logos Publ. ; Progress Publ. 224 p. (In Russ.).

Obzor rossiiskikh intellektual'nykh zhurnalov [A review of Russian intellectual journals] (2004) / V. Morozov and P. Rezvykh. Neprikosnovennyi zapa, no. 2 (34). [online] Available at: http://magazines.russ.ru/nz/2004/34/zh14.html [archived in WaybackMachine] (accessed 12.08.2018). (In Russ.).

Rodchenkov vstretilsia s amerikanskim pravitel'stvom i obsudil ugrozy dlia SShA so storony Rossii [Rodchenkov met with American Government officials and discussed Russia's threats against the USA]. Sports.ru, March 24. [online] 
Available at: https://www.sports.ru/biathlon/1061584117.html [archived in WaybackMachine] (accessed 18.09.2018). (In Russ.).

Sikorskii, D. (2016) Polnaia degumanizatsiia: evropeiskie SMI sdelali iz rossiian monstrov [Complete dehumanization: European mass media made monsters out of Russians]. Ekonomika segodnia, June 15. [online] Available at: https://rueconomics.ru/179299-polnaya-degumanizaciya-evropeiskie-smi-sdelaliiz-rossiyan-monstrov [archived in WaybackMachine] (accessed 28.09.2018). (In Russ.).

Stone, O. and Kuznick, P. (2014) Nerasskazannaia istoriia SShA [The untold history of the United States] / transl. from English by A. Orzhitskii and V. Poliakov. Moscow : KoLibri Publ. ; Azbuka-Attikus Publ. 928 p. (In Russ.).

Tabak, M. (2018) MID Britanii nazval interv'iu «podozrevaemykh» po delu Skripalei lzhivym [Foreign and Commonwealth Office called an interview of "suspects" in the case of Skripals false]. RIA Novosti, September 3. [online] Available at: https://ria.ru/world/20180913/1528486685.html [archived in WaybackMachine] (accessed 14.09.2018). (In Russ.).

Tarasov, A. (2011) Desiatiletie pozora. Tezisy obvinitel'noi rechi [Decade of shame. The theses of the indictment]. Intelros, November 23. [online] Available at: http://www.intelros.ru/subject/figures/aleksandr-tarasov/12113-desyatiletie-pozora -tezisy-obvinitelnoy-rechi.html [archived in WaybackMachine] (accessed 18.07.2018). (In Russ.).

Fakhrutdinov, R. (2018) NATO razberetsia: Britaniia zhaluetsia na otravlenie shpiona [NATO will sort out: Britain complains about the poisoning of a spy]. Gazeta.ru, March 11. [online] Available at: https://www.gazeta.ru/ social/2018/03/11/11678509.shtml [archived in WaybackMachine] (accessed 11. 09.2018). (In Russ.).

Foucault, M. (2002) O prirode cheloveka. Spravedlivost' protiv vlasti [Human nature: Justice versus power]. In: Foucault, M. Intellektualy i vlast' [Intellectuals and power] : Selected political articles, speeches and interviews / transl. from French by S. Ch. Ofertas ; ed. by V. P. Vizgin, and B. M. Skuratov. Moscow : Praksis Publ. 384 p. Pp. 81-147. (Series: Novaia nauka politiki). (In Russ.).

Fursov, A. I. (2013) Serye volki i korichnevye reikhi. Tainaia istoriia poslevoennogo mira. Stat'ia tret'ia [Grey wolves and brown reichs. Secret history of the postwar world. Article 3]. Svobodnaia mysl', no. 4 (1640), pp. 183-196. (In Russ.).

Schiller, H. (1980) Manipuliatory soznaniem [Mind managers]. Moscow : Mysl' Publ. 326 p. (In Russ.).

Engdahl, F. W. (2016) Sviashchennye voiny Zapadnogo mira [Holy wars of the Western world]. Moscow : Selado Publ. 336 p. (In Russ.).

Butler, N. (2018) Rodchenkov meets with members of US Government Agency to discuss Russian doping. Insidethegames.biz, March 24. [online] Available at: https://www.insidethegames.biz/index.php/articles/1063043/rodchenkovmeets-with-members-of-us-government-agency-to-discuss-russian-doping [archived in WaybackMachine] (accessed 11.09.2018). 
Drumbell, J. (1995) The Carter presidency: A re-evaluation. Manchester : Manchester University Press. viii, 235 p.

Submission date: 4.10.2018.

Ильин Алексей Николаевич - кандидат философских наук, доцент кафедры практической психологии Омского государственного педагогического университета. Адрес: 644043, г. Омск, ул. Партизанская 4а, ауд. 117. Эл. адpec: ilin1983@yandex.ru

Ilyin Alexey Nikolaevich, Candidate of Philosophy, Associate Professor, Department of Practical Psychology, Omsk State Pedagogical University. Postal address: Aud. 117, 4a Partizanskaya St., 644043 Omsk, Russian Federation. E-mail: ilin1983@yandex.ru

\section{Для ичитирования:}

Ильин А. Н. Русофобия Запада, построенная на современных событиях: когда идеологемы противостоят реальности [Электронный ресурс] // Горизонты гуманитарного знания. 2019. № 1. C. 14-47. URL: http://journals. mosgu.ru/ggz/article/view/950 (дата обращения: дд.мм.гггг). DOI: 10.17805/ ggz.2019.1.2 